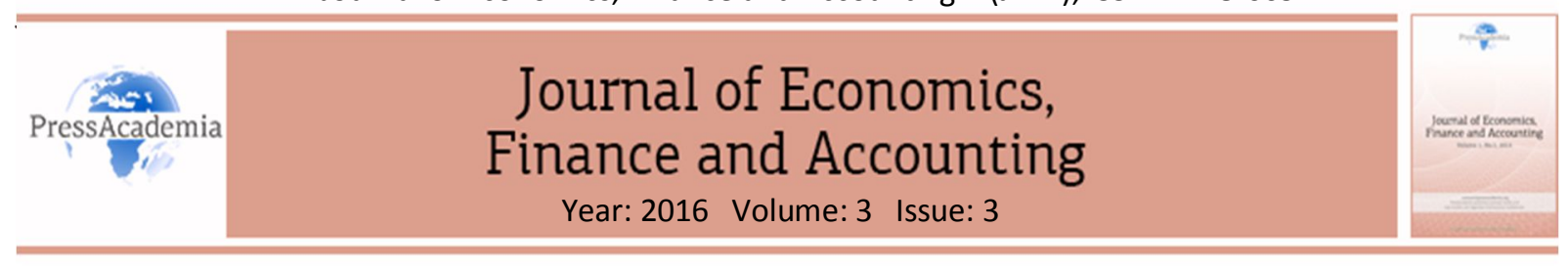

\title{
ANALYSIS AND FORECASTS ON THE HEALTHCARE TOURISM INCOME OF TURKEY
}

\author{
DOI: 10.17261/Pressacademia.2016321990 \\ Onur Koyuncu ${ }^{1}$, Mehmet Gozlu ${ }^{2}$, Kazım Baris Atici ${ }^{3}$ \\ ${ }^{1}$ Hacettepe University. okoyuncu@hacettepe.edu.tr \\ ${ }^{2}$ Hacettepe University. mehmet.gozlu@hacettepe.edu.tr \\ ${ }^{3}$ Hacettepe University. kba@ hacettepe.edu.tr
}

\begin{abstract}
Turkey is one of the new centers of attraction for healthcare tourism with increasing efforts for improvement at policy making level. In link with the specific targets for healthcare tourism income set by the government, this study aims to analyze historical data of healthcare tourism income of Turkey over 2002-2015 and provide future forecasts. Both annual and quarterly healthcare tourism income data are analyzed to investigate the share of healthcare tourism income in aggregate tourism income and to search for seasonal effects. Results indicate that relying on the high correlation between aggregate tourism and healthcare tourism income, healthcare tourism income can be presented and forecasted as a percentage of annual tourism income. Seasonality is observed for the aggregate tourism income, where it is also present for healthcare tourism income between 2002 and 2009. It is also found that Turkey has an upward trend in health and aggregate tourism income.
\end{abstract}

Keywords: Tourism Income, healthcare tourism income, forecasting, Turkey JEL Classification: I11, Z32, C53

\section{INTRODUCTION}

A recent shift in the demand structure followed by a significant increase in the patient mobility can be noted throughout the global healthcare industry due to several reasons such as differing costs, problems in local healthcare supply, increasing awareness as well as the intention to match vacations with medical care. Such a shift has result in establishment of a contemporary type of tourism, namely as Healthcare Tourism and it has begun to hold a major place in the national healthcare systems. Healthcare tourism conceptually consists of medical and thermal tourism, as well as services for the senior and the disabled (Çevirme, 2008; Tütüncü et al., 2011). Although the definition of the term health tourism is relatively recent, the notion has a long history dating back to 1990s. In the earlier stages, the direction was from underdeveloped countries to developed ones and it was mainly addressing the people in search for higher quality services and with resources to travel. Recent decades have experienced a reverse in trend; from developed countries to promising emerging countries, which provide high levels of medical quality for a relatively cheaper price. In that sense, Middle Eastern and Asian countries are becoming a center of attraction (Karuppan and Karuppan, 2010). Turkey is one of those emerging destinations in healthcare tourism with its proximity to Europe and Middle East, its numerous thermal resources and its competitive labor power in health and medical care (Kılınç, 2013).

The aim of this paper is to provide insight on past and future of healthcare tourism income of Turkey. We pursue two main objectives. First, we aim to analyze the share of healthcare tourism income within the aggregate tourism income of Turkey and its change over time followed by the identification of appropriate forecasting approach for future shares. Second, we target investigating the quarterly healthcare tourism income structure for any trends and seasonal effects and coming up with suitable forecasting approach for future income relying on this investigation. The search for seasonal effect is among our objectives because such an effect is a source of debate. Özkurt (2007) suggests that healthcare tourism does not have seasonality and should be uniform among the 12-month period; there are also traces of a higher demand in the summer periods (TÜRSAB, 2014). We aim to analyze the validity of those assertions of the previous research. With the 
recent initiatives of Turkish government to promote healthcare tourism, such analyses are believed to be meaningful for planning the future of healthcare tourism in Turkey. The results may also provide a strategic insight for macro level decision makers in their decisions of marketing, investments and allocation of public resources.

The paper is organized as follows: Section 2 provides a brief insight on the literature of healthcare tourism and basics of Turkey's healthcare tourism. Section 3 describes the data set and methodology. Section 4 is devoted to findings and discussion of results. It consists of 5 main parts where first two is dealing with findings and forecasts using annual data. Sections $4.3,4.4$ and 4.5 presents the findings of analysis on quarterly data. Finally, Section 5 concludes.

\section{LITERATURE REVIEW}

\subsection{Healthcare Tourism}

Healthcare tourism is an emerging, global, multibillion-dollar industry with various stakeholders identified by Gupte and Panjamapirom (2014) as governments, travel industry, transport industry, clinical and non-clinical professionals, hospitals and patients. The number of medical tourists is expected to rise from approximately 10.5 million in 2011 to 23.2 million by 2017 and predicted to generate global revenue of approximately between $\$ 40$ and $\$ 60$ billion (Gupte and Panjamapirom, 2014). Major healthcare tourism destinations are Thailand, Singapore and India in Asia, Mexico, Brazil, and Colombia in Latin America, Jordan, Turkey, and United Arab Emirates (UAE) in the Middle East and Hungary, Poland and Czech Republic in Central-Eastern Europe (Beladi et al., 2015).

Forecasting tourism demand in general is one of the major areas of interest in tourism research. Several papers can be found in the literature analyzing the tourism demand trends and providing future forecasts with a country-wide focus in different countries such as Italy (Guizzardi and Mazzocchi, 2010), Spain (Claveria and Datzira, 2010), Egypt (Andrawis et al., 2011), Hong Kong (Wong et al., 2007) and Taiwan (Wang, 2009) or with a multiple-country focus (Shen et al., 2011). In a recent review, Song and Li (2008) state that the methods used in analyzing and forecasting the demand for tourism are very diverse. According to review by Witt and Witt (1995), no single forecasting method performs consistently best across different situations and this observation does not seem to change much when it has come to 2008.

Recently, with the emerging size of the market, the research on healthcare tourism is also gaining popularity. Several studies are dedicated to analyze the dynamics, trends and economics of healthcare tourism with an international focus (Lautier, 2014; Beladi et al., 2015). Some studies focus on healthcare tourism trends of specific regions such as Huang (2012) providing demand forecast in Asian countries, Lautier (2008) investigating the healthcare exports of Tunisia and Loh (2015) examining health-related travel spending by Canadian citizens for any shifts and trends. There also exists a research stream focusing on dynamics of recreational and wellness tourism, which can also be considered as a part of healthcare tourism (see Sayılı et al., 2007; Joppe, 2010; Csirmaz and Peto 2015).

\subsection{Healthcare Tourism in Turkey}

There are several factors effecting the growth of healthcare tourism industry. Among the most important ones are costs, exchange rates, competition, privatization, marketing, costly operations uncovered by insurances (such as dental or plastic surgery), age distribution of the population, timing of appointments, prohibited operations (such as abortion or gender change), care insurance for the senior and the disabled, medical accreditations (İçöz, 2009). Healthcare tourism choices are also influenced by travelling expenses, availability of direct flight routes, geographical proximity, climate, culture and religion (Aslanova, 2013).

Turkey is a popular destination for healthcare tourism with numerous Joint Commission International (JCl) accredited hospitals, with about $60 \%$ less cost (TÜRSAB, 2014). Shorter waiting times, opportunity to combine medical travel with a holiday, availability of high technology medical equipment and insurance coverage for medical treatments in Turkey also brings out a competitive advantage (Birdir and Tuzcu, 2014; Özok, 2008; Şahbaz et al., 2012). 
According to Turkish Healthcare Tourism Report by Association of Turkish Travel Agencies (TÜRSAB) published in 2014, Turkey mainly offers three types of healthcare tourism services:

- Medical Tourism: Medical or rehabilitative treatment of international patients at medical institutions.

- Thermal Tourism and Medical SPA: Treatment carried out mostly in hotels along with subsidiary medical massage, mud treatment etc.

- Tourism for the Senior and the Disabled: Treatment, care and rehabilitation for the senior and the disabled.

Healthcare tourist profiles choosing Turkey are mostly wealthy Middle Eastern, African or middle class European patients (Çevirme, 2008) who spend around 2000 to 12000 USD per capita (TÜRSAB, 2014) which is almost four times more than that spent by other types of tourists (Bozkurt, 2008). Per capita spending differs significantly between public and private institutions. While average patient spends an average of 9000 USD in public institutions, the average increases to 12000 USD in private counterparts.

The Turkish Ministry of Development has a special interest on healthcare tourism potential of the country and published a section devoted to healthcare tourism in its $10^{\text {th }}$ Development Plan covering the years 2014 to 2018. Table 1 presents the expected income and tourist volume for healthcare purposes, set by the Turkish Ministry of Development. The plan also mentions the objectives of collaboration between related parties, preparation of record keeping and statistical infrastructures, allocation of investment and planning incentives, improvement of personnel in terms of quality and quantity, boosting promotion and marketing for the potential improvements in healthcare tourism (Turkish Ministry of Development, 2014).

Table 1: Turkish Healthcare Tourism Development Plan

\begin{tabular}{lrrrrrr}
\hline Tourism Type and Capacity & $\mathbf{2 0 1 3}$ & $\mathbf{2 0 1 4}$ & $\mathbf{2 0 1 5}$ & $\mathbf{2 0 1 6}$ & $\mathbf{2 0 1 7}$ & $\mathbf{2 0 1 8}$ \\
\hline $\begin{array}{l}\text { Thermal Tourism } \\
\text { Bed Capacity }\end{array}$ & 42,000 & 50,000 & 60,000 & 75,000 & 90,000 & 100,000 \\
$\begin{array}{l}\text { Thermal Tourism } \\
\text { Volume }\end{array}$ & 500,000 & 625,000 & 780,000 & 975,000 & $1,250,000$ & $1,500,000$ \\
$\begin{array}{l}\text { Medical Tourism } \\
\text { Volume }\end{array}$ & 308,500 & 360,000 & 435,000 & 520,000 & 620,000 & 750,000 \\
$\begin{array}{l}\text { Thermal, Medical and Senior } \\
\text { Tourism Income (Billion \$) }\end{array}$ & 2.75 & 3.40 & 4.45 & 5.85 & 7.60 & 9.35 \\
\hline
\end{tabular}

Turkey has realized its potential in health tourism industry at a policy making level and has taken big steps to make a leap in the last decade. Goals are set, institutional changes are carried out; plans are made and put in progress. International Health Tourism Congress has been organized since 2008 and Department of Health Tourism operating under the control of Turkish Ministry of Healthcare since 2011 has been founded. Considering that, we aim to contribute to healthcare tourism literature for Turkey by examining the historical data of the industry over years through following methodology.

\section{DATA AND METHODOLOGY}

This paper aims to analyze historical data on healthcare tourism income in Turkey in order to identify any pattern or trends for providing insight for future. Relying on our objectives, the analysis design is composed of two main parts:

- Analysis on the share of healthcare tourism income in the aggregate tourism income of Turkey

- Investigation of any seasonal effects in the healthcare tourism income of Turkey

To fulfill our first objective, annual tourism and healthcare tourism income data are examined. For the second objective, quarterly healthcare income data are used. The data are extracted from the records of Turkish Statistical Institute (TURKSTAT) (www.turkstat.gov.tr). TURKSTAT claims to have corrected the data for a possible bias which may have been caused by the immigrants entering Turkey related to the conflicts in the 
Middle East region. The time frame is 2002 to 2015 where reliable data can be obtained. For simplicity, we limit our approach to income generated by tourism.

The analyses consist of correlation and regression analyses to bring out annual trends and possible dependencies, chi square goodness of fit tests to analyze the shares of health related income among aggregate tourism income and static forecasting methods with Mean Absolute Percentage Error (MAPE) minimization to check for seasonality. Microsoft Excel is utilized for all empirical analysis and production of figures.

\section{FINDINGS AND DISCUSSIONS}

\subsection{Annual Analysis on the Share of Healthcare Tourism Income in Aggregate Tourism Income}

a) Annual Tourism Income: We begin our analysis to obtain a general overview of aggregate tourism income of Turkey. Figure 1 presents the annual tourism income (in million Turkish Liras) for the 2002-2015 periods.

Figure 1: Annual Tourism Income of Turkey between 2002 and 2015

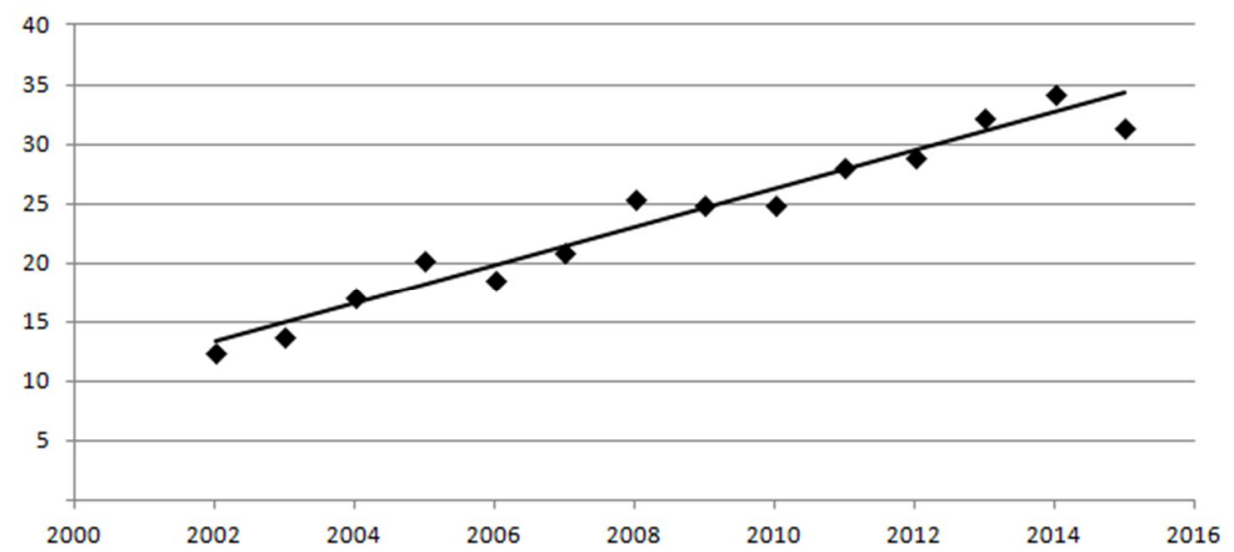

An obvious linear upward trend can easily be noticed in Figure 1. The Pearson Correlation Coefficient is obtained as 0.976 between time and income. This relationship can be expressed as a linear regression model since the numerical data displays a high linear correlation. Such a model yields the below linear equation where $A I, Y$ and $\varepsilon$ represent annual tourism income (in million Turkish Liras), year and residuals respectively. The index $i$ represent time. The calculated Mean Absolute Percentage Error (MAPE) for this regression reveals a $5.34 \%$ error, which is acceptable.

$$
A I_{i}=13.42+1.6 Y_{i}+\varepsilon_{i}
$$

Three unanticipated falls in the annual tourism income can be observed in years 2006, 2010 and 2015 from Figure 1. These may coincide with the U.S. based subprime mortgage crisis, European debt crisis and the conflicts in Syria respectively since all turned out to be international crises effecting the Turkish region in a severe manner. Yet, the general linearity assumption does not seem to be weakened under the influence of these events.

b) Annual Healthcare Tourism Income: Accommodation, transportation and feeding incomes as well as the healthcare tourism income are some of the components of aggregate tourism income. In Figure 2 below, we examine the annual healthcare tourism income (in million Turkish Liras) along with those components of tourism income, which we presume that they may be related. 
Figure 2: Annual Income from Healthcare, Accommodation, Transportation and Feeding

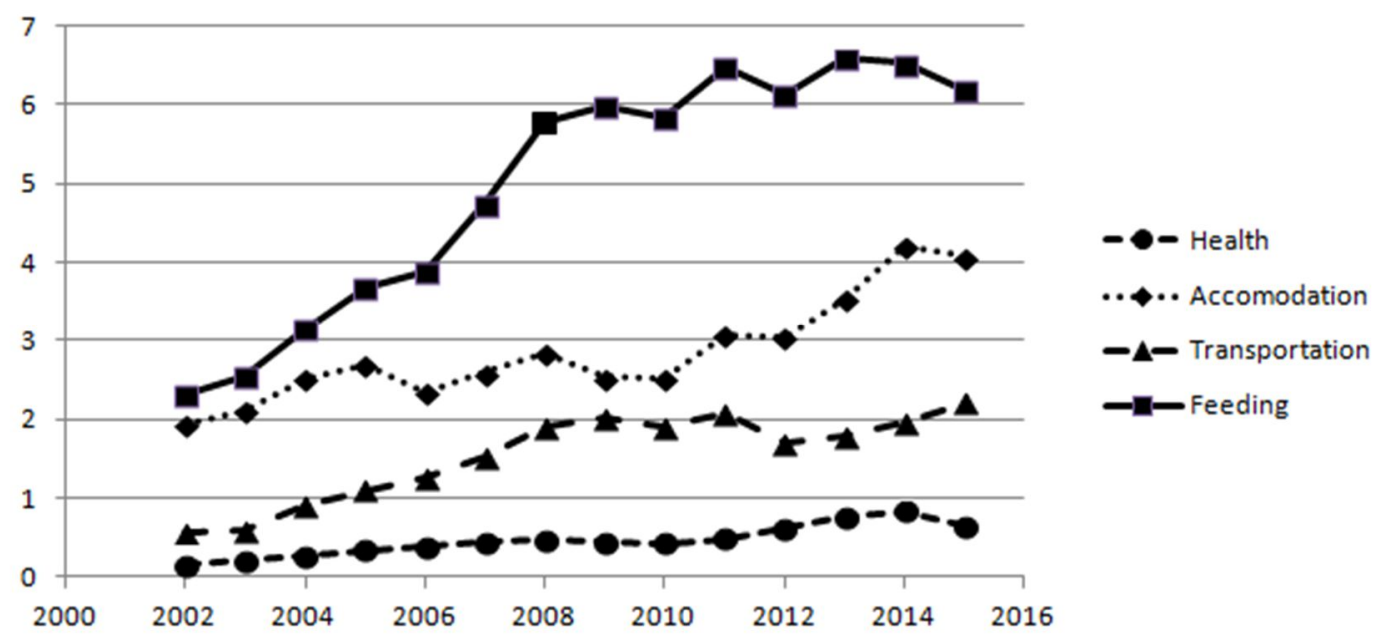

As can be readily observed, healthcare tourism has the lowest share among the four; still, it has an upward trend. A closer look at healthcare tourism income and aggregate tourism income presented in Figure 1 reveals that there is a better link between aggregate tourism income and healthcare income rather than the remaining three components of tourism income. Figure 3 presents this fact using normalized $(\mu / \sigma)$ scores of both variables, where annual healthcare tourism income faces two declines at 2010 and 2015 otherwise revealing an overall upward trend. The change in the data is quite similar to the aggregate tourism income but the effects of breaking points defined above (in years 2006, 2010 and 2015) on healthcare tourism income seem to be more intense than the aggregate tourism income.

Figure 3: Normalized Annual Healthcare and Aggregate Tourism Income Data for Turkey

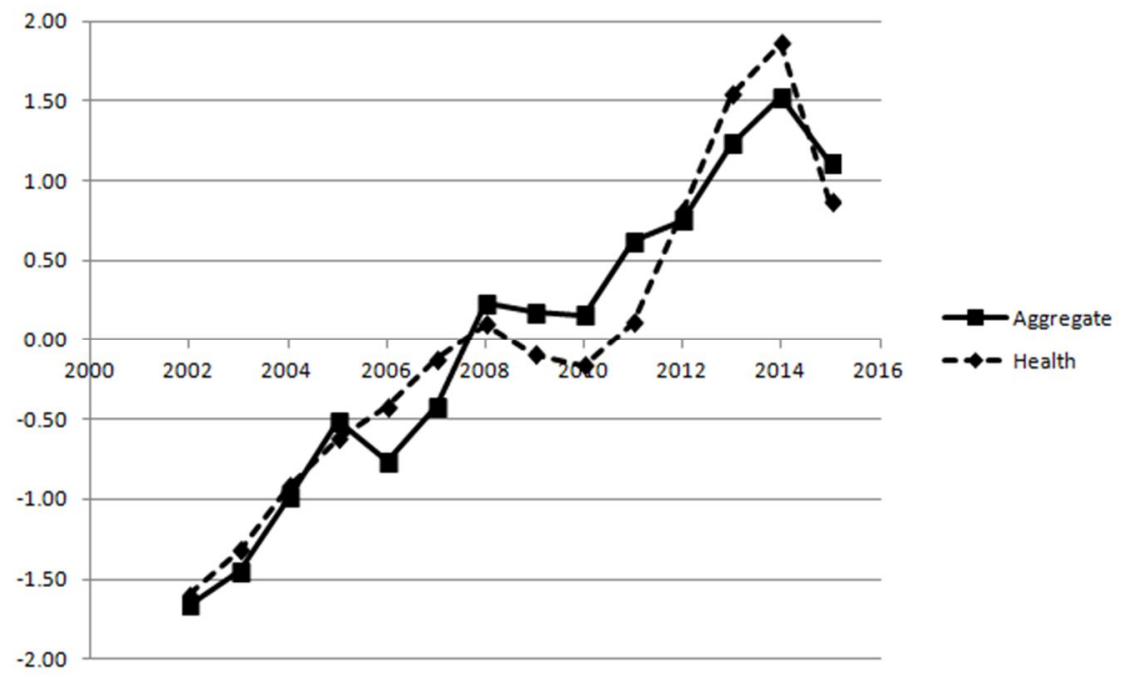

c) The shares: Healthcare tourism income have a correlation of 0.932 with time and 0.963 with annual aggregate tourism income, which points out an almost perfect relationship. Therefore, once the required verifications are presented, it may be possible to suggest that healthcare tourism income have a definable share in and can be presented and forecasted as a percentage of annual aggregate tourism income. Considering that, we present the shares of health income among aggregate tourism income. The share has an average of $1.9 \%$ with a standard deviation of $0.35 \%$ annually. 


\subsection{Forecasting the Share of Healthcare Tourism Income with Annual Data}

The chi-square goodness of fit tests carried out on both normalized scores and the shares result in a uniform share structure of $1.9 \%$ with respective $p$-values of 0.99 and 1.00 . Yet, the trend in the shares has an overall positive direction. These are modelled by linear regression, a power four polynomial regression and a two term moving averages. The three models resulted in $10.48 \%, 8.33 \%$ and $4.44 \%$ MAPE values respectively. Therefore, it can be argued that the best way to predict the shares of health among aggregate tourism income is to use an adaptive strategy of moving averages. The share data and the fitted models can be found in Figure 4 and the resulting error terms are depicted in Figure 5.

\section{Figure 4: Share Data and Fitted Models}

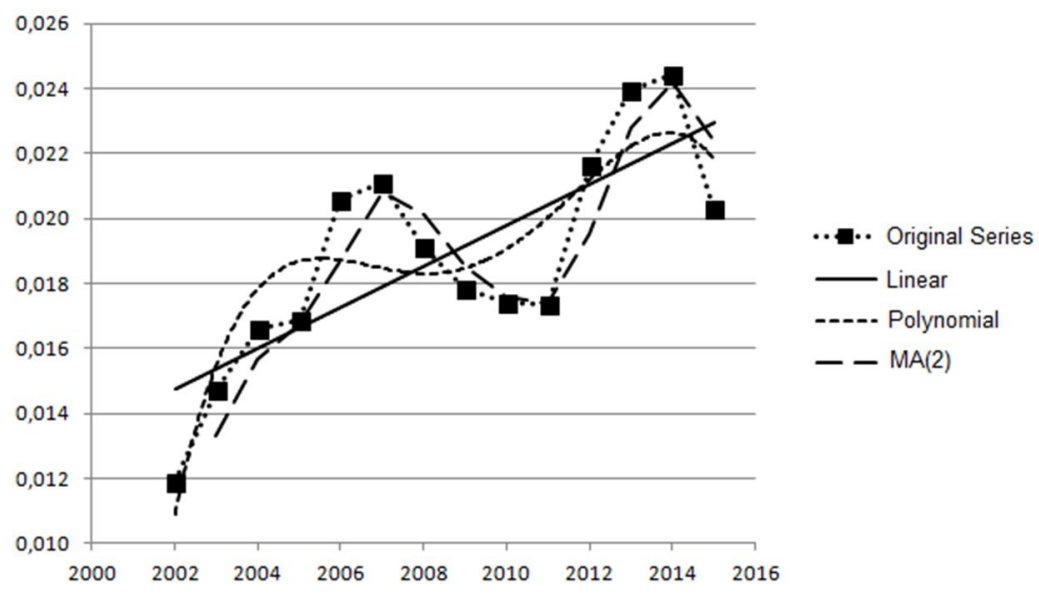

Figure 5: The Error Terms from Fitted Models

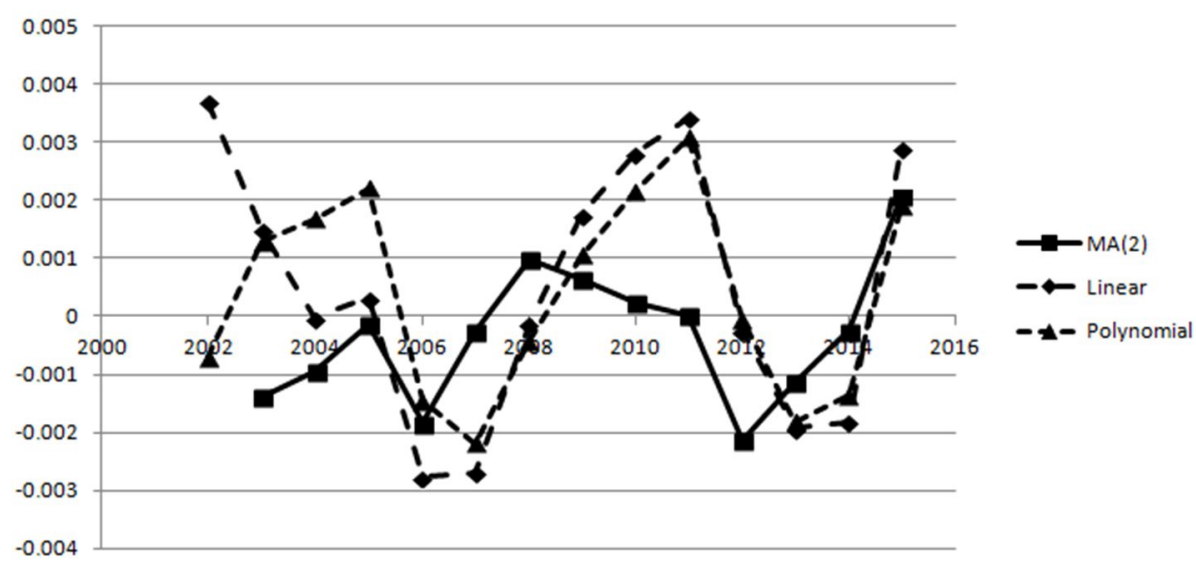

Although the best practice for predicting annual healthcare tourism income share seem to be moving averages approach, still, a linear model can be utilized, for its simplicity in calculation. In addition, moving averages require the assumption of no trend whereas a trend in data is immediately observed. For the polynomial approach it can be argued that a polynomial curve may frequently change direction or tend to rise or fall limitlessly after a critical value. This is a tough assumption to make. Therefore, a linear model would still be valid based on the goodness of fit tests. For this purpose, following linear model without an intercept can be applied to forecast the healthcare tourism income as the share of aggregate tourism income.

$$
F C_{\text {health }, i}=0,19 * F C_{a g g, i}+\varepsilon_{i}
$$




\subsection{Investigation of Seasonality in Healthcare Tourism Income with Quarterly Data}

In this section, we aim to fulfill our second objective and investigate seasonality in healthcare tourism income. The existence of seasonality would provide new perspective for forecasting. In this and following sections, quarterly data between 2002 and 2015 are of our interest. In order to avoid scale effect of aggregate and healthcare tourism income, we present both variables using normalization in Figure 6.

Figure 6: Quarterly Aggregate and Healthcare Tourism Income for Turkey between 2002-2015

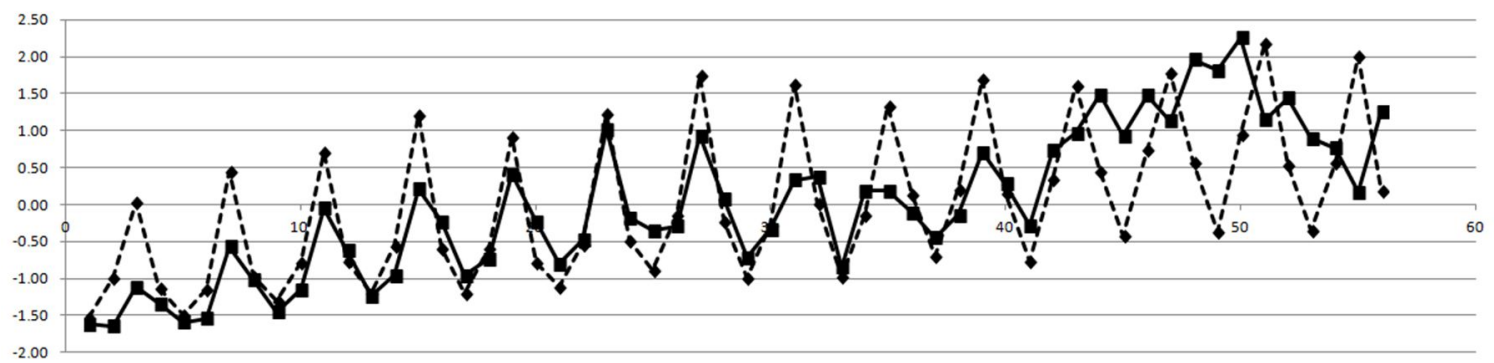

An upwards trend and a clear seasonality is obvious for the aggregate tourism income (the dashed series with a larger variation) from Figure 6. In terms of healthcare tourism incomes, seasonality seems to be weakened after 2008. At this point, let us also examine the state of the shares of healthcare tourism income in the aggregate tourism income. Figure 7 reveals that the shares have a systematic seasonality pattern with higher values in winter and lower values in summer. The shares for quarterly data reveal a $\mathbf{2 . 1 \%}$ average and $\mathbf{0 . 7 3 \%}$ standard deviation. The mean value is close to the previous finding with the annual data (1.9\%); however, the standard deviation is doubled with the use of quarterly data. This can easily be justified with the fact that Turkey has a high tourism demand during summer, attracting tourists for vacation purposes that may lead to the healthcare tourism shares to fall, followed by a higher deviation in data.

Figure 7: Shares of Health Tourism Income among Aggregate Tourism Income (Quarterly)

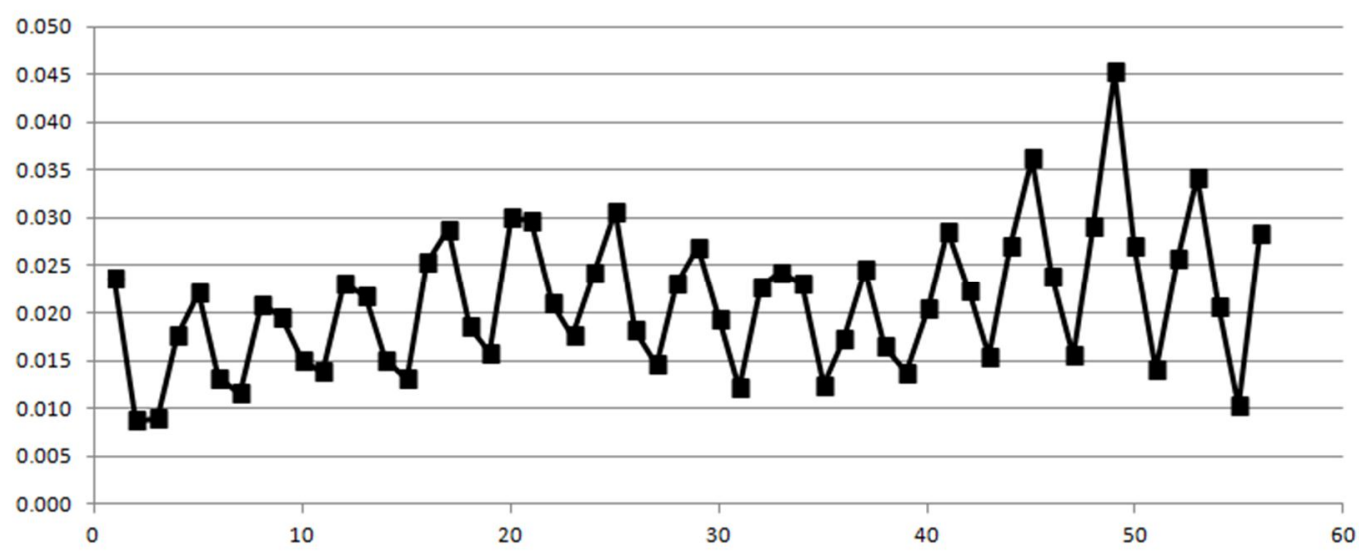

In order to evaluate the changes in the seasonality for healthcare tourism income from 2008 (as observed in Figure 6, we explore the summer to winter ratios of healthcare tourism income and come up with interesting results. Figure 8 presents the summer to winter healthcare tourism income ratios. Until 2008, the summer periods generate significantly larger aggregate income than any other quarters. From this time onwards, the healthcare tourism income has a uniform shape across the quarters. The uniformity begins from 2008 and 2009, followed by a downward trend from 2012. When the Turkish government officially put effort on healthcare tourism beginning from 2008 by voicing a concern and focus and promotion of healthcare tourism, things started to change. The downward trend after 2012 reveals that summer and winter healthcare tourism incomes are approaching to each other, which can mean that efforts on policy making on healthcare tourism pays well. 
Figure 8: Summer to Winter Healthcare Income Ratios

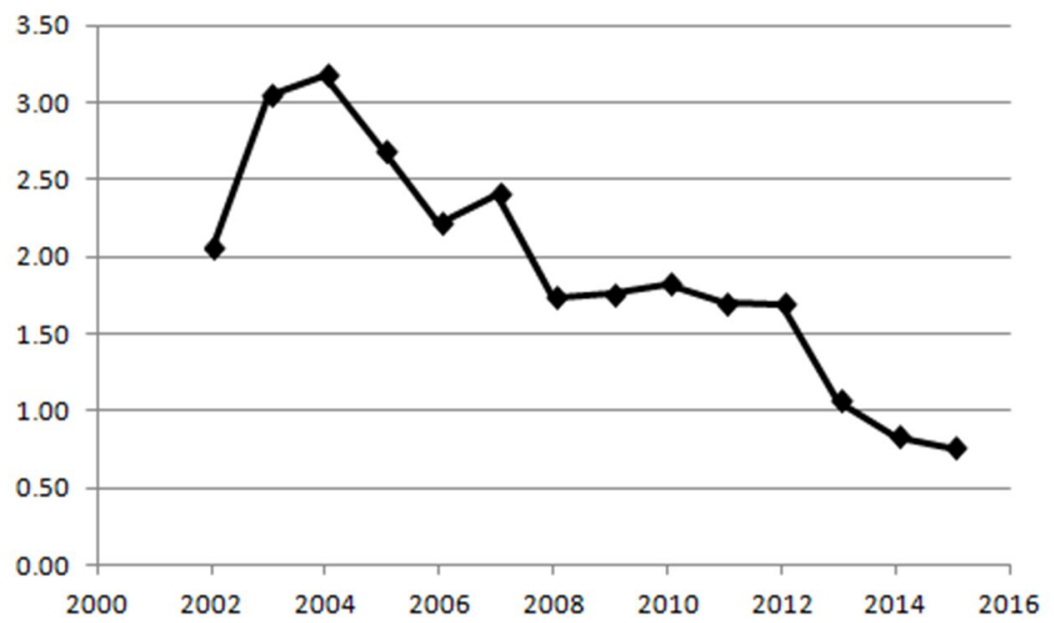

\subsection{Forecasting the Healthcare Tourism Income with Quarterly Data (2002-2009)}

As similar to the annual analysis conducted in sections 4.1 and 4.2, quarterly goodness of fit tests on both normalized scores and the shares result in a uniform share structure of $2.1 \%$ in this case and $p$ - values are 0.91 and 1.00 , respectively. We can conclude that a certain share is observed throughout the 14-year period. Therefore, it is valid to assert that the healthcare tourism income can be estimated as a portion of aggregate tourism income both in an annual and quarterly manner. There are two cautions to be forwarded still. First, on the aggregate level the effects of global crises shall not be underestimated. Secondly, on the quarterly level the recent health tourism campaign of Turkish government has started to alter the previous demand structure to a more uniform shape. These must be taken into account.

Considering the change in seasonality detected earlier, it would be wise to divide the healthcare income into two parts in order to come up with appropriate forecasts. The first part (2002Q2 to 2009Q3) is given in Figure 9 and the seasonality can easily be detected.

Figure 9: Healthcare Tourism Income Between 2002Q2 to 2009 Q3

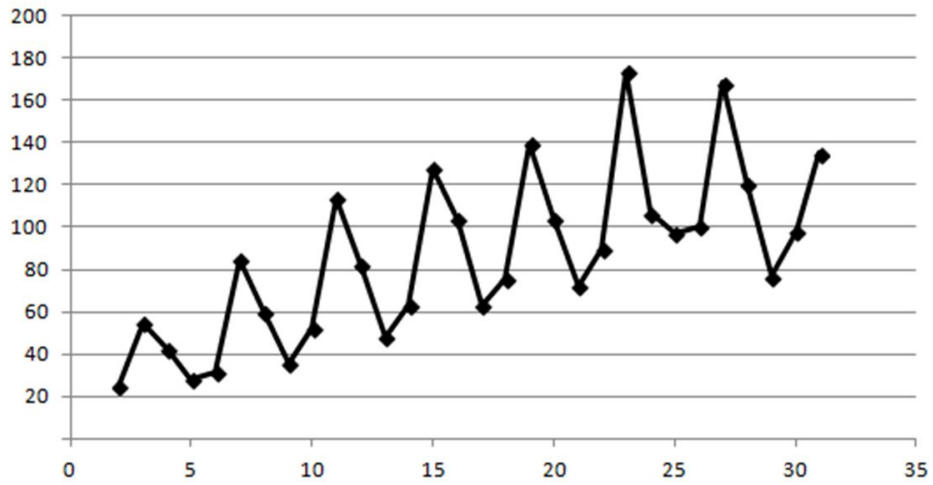

Except for the triplet around Q25, a clear seasonal structure is present for an eight-year period. We apply a static forecasting methodology incorporating periods $(P)$ to estimate the level $(L)$, trend $(T)$ and seasonal factors $(S F)$. Three models considering additive, multiplicative and mixed functions of those parameters as:

- Additive Model: $F C=L+T x P+S F_{Q}$ where all parameters are in additional form

- Multiplicative Model: $F C=L x T^{P} \times S F_{Q}$ where all parameters are in multiplicative form

- Mixed Model: $F C=(L+T x P) \times S F_{Q}$ where only $S F$ is in the multiplicative form 
To obtain the forecast parameters $L, T$ and $S F$, the data is smoothed using moving averages with MA (5) in order to eliminate the seasonal effect. Then, a linear regression (nonlinear in multiplicative model) is applied to obtain $L$ and $T$. Using the original income with the regression results $S F$ values are calculated and then averaged for forecasting. Forecasts are made and error terms are evaluated to obtain the standard deviations and MAPE values. Our findings for the three methods subject to MAPE minimization are given in Table 2.

Table 2: Static Forecast Results of Healthcare Income Between 2002-2009

\begin{tabular}{lccc} 
Model & $\begin{array}{c}\text { Mathematical Representation } \\
\text { (in thousands) }\end{array}$ & $\begin{array}{c}\text { Standard Deviation of the Error Terms } \\
\text { (in thousands) }\end{array}$ & MAPE \\
\hline Additive & $42.8+3 \times \mathrm{P}+\mathrm{SF}_{\mathrm{Q}}$ & 12.4 & $10.4 \%$ \\
Multiplicative & $42.3 \times 1.04^{\mathrm{P}} \times \mathrm{SF}_{\mathrm{Q}}$ & 19.8 & $15.1 \%$ \\
Mixed & $(27.7+3.7 \times \mathrm{P}) \times \mathrm{SF}_{\mathrm{Q}}$ & 16.3 & $9.4 \%$ \\
\hline
\end{tabular}

The forecast graphs are presented in Figure 10. Additive and mixed forecasts are fairly acceptable, providing sufficient evidence of a seasonal structure and positive direction in the healthcare tourism income. The additive model adapts to change faster with a smaller variation, whereas the mixed model performs better with a smaller MAPE.

Figure 10: Static Forecasts of Quarterly Health Tourism Income (2002Q2 to 2009Q3)

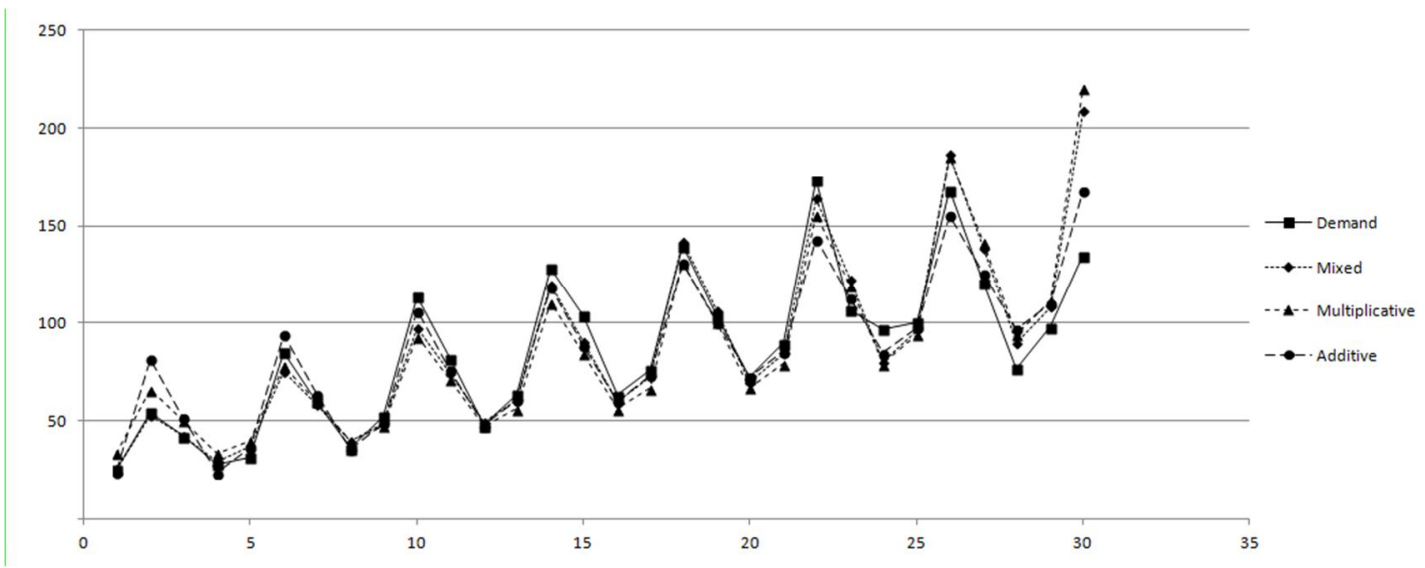

\subsection{Healthcare Tourism Income after 2009}

Beginning from 2009, the seasonal structure becomes weaker, before completely disappearing in 2012. Figure 11 shows the remaining data (from Figure 9) where the seasonal structure is broken. 


\section{Figure 11: Healthcare Tourism Income Between 2009Q4 to $2015 Q 4$}

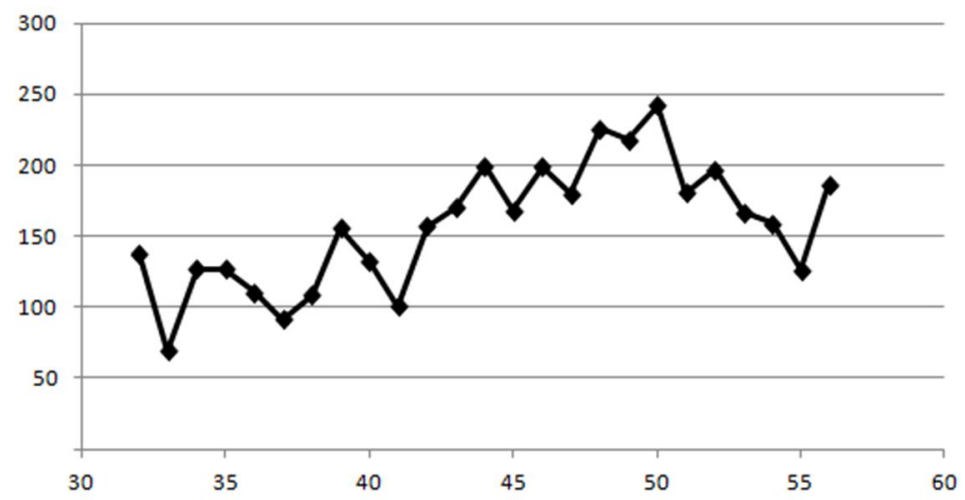

In 2008, there has been two important developments in Turkey on health tourism. The Department of Health Tourism was first introduced as a competent body and Turkish Ministry of Health debuted the annual International Health Tourism Congress. These advances have aimed to manipulate the healthcare tourism income. The result was an upward trend, later interrupted by the conflicts in Syria, and a more uniform income structure across the quarters (Figure 10). This shift in demand also modified the previous seasonal pattern to a more random shape. The traces of the previous seasonality can still be found between Q32-Q43, which then diminishes to a random fluctuation. Relying on the more recent data, it can be concluded that there are no seasonal patterns in the healthcare tourism income anymore.

\section{CONCLUSION}

Healthcare tourism is an emerging market open for international competition. The popular destinations are shifting through time and are affected by global affairs. In this study, we examine the case of Turkey aiming to provide insight on past and future of healthcare tourism income of Turkey. The analysis can be thought in two main parts relying on the data: annual and quarterly.

Annual analysis on aggregate and healthcare tourism income data between 2002 and 2015 reveal several observations. First of all, a linear upward trend can be observed in Turkish aggregate tourism income. Secondly, healthcare tourism income has also an upward trend. In addition, healthcare tourism income is significantly correlated with aggregate tourism income, therefore, healthcare tourism income has a definable share in and can be presented and forecasted as a percentage of annual aggregate tourism income. The share of healthcare tourism in aggregate tourism has an average of $1.9 \%$ with a standard deviation of $0.35 \%$ annually. Finally, the best practice for predicting annual healthcare tourism income share found to be moving averages approach, however a linear model can also be utilized, since moving averages require the assumption of no trend whereas a trend in our data is immediately observed.

Quarterly analysis on aggregate and healthcare tourism income data between 2002 and 2015 indicate following results. An upwards trend and a clear seasonality is obvious for the aggregate tourism income. Healthcare tourism income data reveals seasonality, however, beginning from 2009, the seasonal structure becomes significantly weaker, before completely disappearing in 2012. This corresponds to the time period that the Turkish government officially put effort on healthcare tourism beginning from 2008 by voicing a concern and focus and promotion. Considering the change in seasonality, we can divide the healthcare income into two parts: 2002Q2 to 2009Q3 and 2009Q3 to 2015Q4. We apply three forecast methods subject to Mean Absolute Percentage Error minimization to 2002Q2 to 2009Q3 data where seasonality is observed: additive, multiplicative and mixed models. It is found that mixed model performs with a smaller MAPE. Relying on data after 2009, it can be concluded that there are no seasonal patterns in the healthcare tourism income anymore.

Even though quarterly healthcare tourism income follows a seasonal pattern until 2009, this structure is seemed to be broken in the following periods. Still, the aggregate tourism income continues to exhibit seasonality. Keeping this in mind and the fact that health tourism has a statistically significant and constant 
annual share in aggregate tourism income, further research may be carried out by focusing on the quarterly share relationship between the two. In a possible case where such a relationship exists, multiple separate mathematical models can be utilized to obtain a better final forecast.

Overall, Turkey has an increasing healthcare tourism potential strengthening with the realization of this potential by the policy makers. Its share in the aggregate tourism incomes is increasing and becoming smoother over the year. The results of the current paper can provide a strategic insight for macro level decision makers in their decisions on healthcare tourism planning.

\section{REFERENCES}

Andrawis, R.R., Atiya, A.F. \& El-Shishiny, H. 2011, “Combination of Long Term and Short Term Forecasts, with Application to Tourism Demand Forecasting", International Journal of Forecasting, vol. 27, pp. 870-886.

Aslanova, K. 2013, “Türkiye'de Sağlık Turizmi ve Sağlık Turizmi Hukuku”, Avrasya Uluslararası Araştırmalar Dergisi, vol. 2, no.3, pp. $129-145$.

Beladi, H., Chao, C.C., Shan Ee, M. \& Hollas, D. 2015, "Medical Tourism and Health Worker Migration in Developing Countries", Economic Modelling, vol. 46, pp. 391-396.

Birdir, K. \& Tuzcu, Z. 2014, "JCl Akreditasyon Belgesine Sahip Olan Sağlık Kuruluşlarının WEB Sitelerinin Medikal Turizm Açısından Değerlendirilmesi”, Çağ Üniversitesi Sosyal Bilimler Dergisi, vol.11, no.1, pp. 1-19.

Bozkurt, H. 2008, “Health Doesn't Listen to Crisis”, Health Tourism Occupational-Political-Cultural Journal, vol. 1, no. 6, pp. 21-23.

Claveria, O. \& Datzira, J. 2010, “Forecasting Tourism Demand Using Consumer Expectations”, Tourism Review, vol. 65, no. 1, pp. 18-36.

Csirmaz, E. \& Peto, K. 2015, “Emerging Markets Queries in Finance and Business International Trends in Recreational and Wellness Tourism", Procedia Economics and Finance, vol. 32, pp.755-762.

Çevirme, F. 2008, "Global Economic Crisis Increases the Importance of Health Tourism”, Health Tourism Occupational-Political-Cultural Journal, vol. 1, no. 5, pp. 9-11.

Guizzardi, A. \& Mazzocchi, M. 2010, "Tourism Demand for Italy and the Business Cycle”, Tourism Management, vol. 31, pp. 367-377.

Gupte, G. \& Panjamapirom, A. 2014. “Understanding Medical Tourism”, Encyclopedia of Health Economics, vol. 3, pp. 404-410.

Huang, Y. 2012, "Forecasting the Demand for Health Tourism in Asian Countries Using a GM (1,1)-Alpha Model", Tourism and Hospitality Management, vol. 18, no.2, pp. 171-181.

İçöz, O. 2009, "Sağlık Turizmi Kapsamında Medikal (Tıbbi) Turizm ve Türkiye'nin Olanakları", Journal of Yaşar University, vol. 4, no.14, pp.2257-2279.

Joppe, M. 2010, “One Country's Transformation to SPA Destination: The Case of Canada” Journal of Hospitality and Tourism Management, vol. 17, pp. 117-126.

Karuppan, C.M. \& Karuppan M. 2010, “Changing Trends in Health Care Tourism”, The Health Care Manager, vol. 29, no. 4, pp. 349-358.

Kılınç, E. 2013, “Medikal Sağlık Turizminin Stratejik Planlaması: Isparta Örneği”, Unpublished Master Thesis, Isparta: Süleyman Demirel University.

Lautier, M. 2008, "Export of Health Services from Developing Countries: The Case of Tunisia", Social Science \&Medicine, vol.67, pp. 101110 .

Lautier, M. 2014, “International Trade of Health Services: Global Trends and Local Impact”, Health Policy, vol. 118, pp. 105-113.

Loh, C.A. 2015, "Trends and Structural Shifts in Health Tourism: Evidence from Seasonal Time-Series Data on Health-Related Travel Spending by Canada during 1970-2010", Social Science \&Medicine, vol. 132, pp. 173-180.

Özkurt, H. 2007, "Sağlık Turizmi Tahvilleri", Maliye Dergisi, Vol. 152, pp.121-142.

Özok, G. 2008, "Thermal Tourism Investments in Turkey”, Health Tourism Occupational-Political-Cultural Journal, vol. 1, no. 6, pp. 16-20.

Republic of Turkey Ministry of Development, 2014, "The Tenth Development Plan 2014-2018", http://www.mod.gov.tr/Lists/RecentPublications/Attachments/75/The\%20Tenth\%20Development\%20Plan\%20(2014-2018).pdf Accessed 15.02.2016.

Sayılı, M., Akca, H. Duman, T. \& Esengün, K. 2007, “Psoriasis Treatment via Doctor Fishes as Part of Health Tourism: A Ca se Study of Kangal Fish Spring, Turkey", Tourism Management, vol. 28, pp. 625-629.

Shen, S., Li, G. \& Song, H. 2011, “Combination Forecasts of International Tourism Demand”, Annals of Tourism Research, vol. 38, no.1, pp. 72-89. 
Song, H. \& Li, G. 2008, "Tourism Demand Modelling and Forecasting - A Review of Recent Research", Tourism Management, vol. 29, pp. 203-220

Şahbaz, R.P., Akdu, U. \& Akdu, S. "Türkiye'de Medikal Turizm Uygulamaları; İstanbul ve Ankara Uygulamaları”, Balıkesir Üniversitesi Sosyal Bilimler Enstitüsü Dergisi, vol. 15, no.27, pp. 267-296.

TÜRSAB 2014, “Turkish Healthcare Tourism Report” (http://www.tursab.org.tr/dosya/12186/saglikturizmiraporu_12186_5485299.pdf Accessed 15.02.2016).

Tütüncü, Ö., Kiremitçi, İ. \& Çalışkan, U. 2011, “Sağlık Turizmi, Güvenlik ve Kalite”, Anatolia: Turizm Araştırmaları Dergisi, vol. 22, no. 1, pp. 91-93.

Wang, Y. 2009, "The Impact of Crisis Events and Macroeconomic Activity on Taiwan's International Inbound Tourism Demand", Tourism Management" vol. 30, no. 1, pp. 75-82.

Witt, S.F. \& Witt, C.A. 1995, "Forecasting Tourism Demand: A Review of Empirical Research", International Journal of Forecasting, vol. 11, pp. $447-475$

Wong, K.K.F., Song, H., Witt, S.F. \& Wu, D.C. 2007, "Tourism Forecasting: To Combine or not to Combine?", Tourism Management, vol. 28, pp. 1068-1078. 